\title{
DIREITO À EDUCAÇÃO: DIREITO À IGUALDADE, DIREITO À DIFERENÇA
}

\author{
CARLOS ROBERTO JAMIL CURY \\ Pontifícia Universidade Católica de Minas Gerais \\ Presidente da Câmara de Educação Básica do Conselho Nacional de Educação \\ crjcury.bh@terra.com.br
}

\begin{abstract}
RESUMO
O artigo estuda a importância do direito à educação escolar, que, mais do que uma exigência contemporânea ligada aos processos produtivos e de inserção profissional, responde a valores da cidadania social e política. Buscam-se no processo histórico da modernidade, no acervo doutrinário e no conjunto normativo, inclusive internacional, as bases desses valores. DIREITO Aं EDUCAÇÃO - IGUALDADE DE OPORTUNIDADES - ACESSO Aं ESCOLA
\end{abstract}

\section{ABSTRACT}

The article studies the importance of the right to a school education, which is viewed as something beyond the contemporary demand linked to the processes of production and professional inclusion, as a response to the values of social and political citizenship. It seeks the bases for these values in the historical process of modernity, in the national and international norms and legislations.

RIGHT TO EDUCATION - EQUAL EDUCATION - ACCESS TO SCHOOL 
Num momento em que a cidadania enfrenta novos desafios, busca novos espaços de atuação e abre novas áreas por meio das grandes transformações pelas quais passa o mundo contemporâneo, é importante ter o conhecimento de realidades que, no passado, significaram e, no presente, ainda significam passos relevantes no sentido da garantia de um futuro melhor para todos.

O direito à educação escolar é um desses espaços que não perderam e nem perderão sua atualidade.

Hoje, praticamente, não há país no mundo que não garanta, em seus textos legais, o acesso de seus cidadãos à educação básica. Afinal, a educação escolar é uma dimensão fundante da cidadania, e tal princípio é indispensável para políticas que visam à participação de todos nos espaços sociais e políticos e, mesmo, para reinserção no mundo profissional.

Não são poucos os documentos de caráter internacional, assinados por países da Organização das Nações Unidas, que reconhecem e garantem esse acesso a seus cidadãos. Tal é o caso do art. XXVI da Declaração Universal dos Direitos do Homem, de 1948. Do mesmo assunto ocupam-se a Convenção Relativa à Luta contra a Discriminação no Campo do Ensino, de 1960, e o art. 13 do Pacto Internacional dos Direitos Econômicos, Sociais e Culturais, de 1966.

Mais recentemente temos o documento de Jomtien, que abrange os países mais populosos do mundo. São inegáveis os esforços levados adiante pela Unesco no sentido da universalização do ensino fundamental para todos e para todos os países.

Mas como se trata de um direito reconhecido, é preciso que ele seja garantido e, para isso, a primeira garantia é que ele esteja inscrito em lei de caráter nacional.

O contorno legal indica os direitos, os deveres, as proibições, as possibilidades e os limites de atuação, enfim: regras. Tudo isso possui enorme impacto no cotidiano das pessoas, mesmo que nem sempre elas estejam conscientes de todas as suas implicações e conseqüências.

Segundo Bobbio,

a existência de um direito, seja em sentido forte ou fraco, implica sempre a existência de um sistema normativo, onde por "existência" deve entender-se tanto o mero fator exterior de um direito histórico ou vigente quanto o reconhecimento de um conjunto de normas como guia da própria ação. A figura do direito tem como correlato a figura da obrigação. (1992, p. 79-80) 
Certamente que, em muitos casos, a realização dessas expectativas e do próprio sentido expresso da lei entra em choque com as adversas condições sociais de funcionamento da sociedade em face dos estatutos de igualdade política por ela reconhecidos. É inegável também a dificuldade de, diante da desigualdade social, instaurar um regime em que a igualdade política aconteça no sentido de diminuir as discriminações. Além disso, muitos governos proclamam sua incapacidade administrativa de expansão da oferta perante a obrigação jurídica expressa.

É por essas razões que a importância da lei não é identificada e reconhecida como um instrumento linear ou mecânico de realização de direitos sociais. Ela acompanha o desenvolvimento contextuado da cidadania em todos os países. A sua importância nasce do caráter contraditório que a acompanha: nela sempre reside uma dimensão de luta. Luta por inscrições mais democráticas, por efetivações mais realistas, contra descaracterizações mutiladoras, por sonhos de justiça. Todo o avanço da educação escolar além do ensino primário foi fruto de lutas conduzidas por uma concepção democrática da sociedade em que se postula ou a igualdade de oportunidades ou mesmo a igualdade de condições sociais.

Hoje cresceu, enfim, a importância reconhecida da lei entre os educadores, porque, como cidadãos, eles se deram conta de que, apesar de tudo, ela é um instrumento viável de luta porque com ela podem-se criar condições mais propícias não só para a democratização da educação, mas também para a socialização de gerações mais iguais e menos injustas.

É preciso considerar que a inscrição de um direito no código legal de um país não acontece da noite para o dia. Trata-se da história da produção de um direito e que tem sua clara presença a partir da era moderna. Segundo Bobbio:

Não existe atualmente nenhuma carta de direitos que não reconheça o direito à instrução - crescente, de resto, de sociedade para sociedade - primeiro, elementar, depois secundária, e pouco a pouco, até mesmo, universitária. Não me consta que, nas mais conhecidas descrições do estado de natureza, esse direito fosse mencionado. A verdade é que esse direito não fora posto no estado de natureza porque não emergira na sociedade da época em que nasceram as doutrinas jusnaturalistas, quando as exigências fundamentais que partiam daquelas sociedades para chegarem aos poderosos da Terra eram principalmente exigências de liberdade em face das Igrejas e dos Estados, e não ainda de outros bens, como o da instrução, que somente uma sociedade mais evoluída econômica e socialmente poderia expressar. (1992, p. 75)

Apesar desse direito não constar do estado de natureza ou mesmo entre os chamados direitos naturais, será no contexto da aceitação ou da recusa a essa forma 
de encarar o nascimento da sociedade moderna que a instrução lentamente ganhará destaque. Ora ela é o caminho para que as Luzes (Universais) se acendam em cada indivíduo, a fim de que todos possam usufruir da igualdade de oportunidades e avançar diferencialmente em direção ao mérito, ora ela é uma função do Estado a fim de evitar que o direito individual não disciplinado venha a se tornar privilégio de poucos.

Com efeito, as luzes da razão, com suas leis racionais, supõem a atualização nos seres racionais de modo a poder realizar o interesse de todos em cada qual. A realização do interesse de cada um, interesse esse racional e oposto ao universo passional, é tido como um valor que impulsiona a ação do indivíduo tendo em vista o princípio da responsabilidade individual. De acordo com este princípio, cada pessoa, cada cidadão deveria ser capaz de garantir-se a si mesmo e a seus dependentes, não cabendo a intervenção do Estado (Oliveira, p. 160, 2000).

E uma das condições para o advento dessa "racionalidade iluminada" e interessada, própria da sociedade civil enquanto universo do privado, é a instrução, à medida que ela abre espaço para a garantia dos direitos subjetivos de cada um. E como nem sempre o indivíduo pode sistematizar esse impulso, como nem sempre ele é, desde logo, consciente desse valor, cabe a quem representa o interesse de todos, sem representar o interesse específico de ninguém, dar a oportunidade de acesso a esse valor que desenvolve e potencializa a razão individual. Mas, segundo John Locke, esta é uma possibilidade a ser construída.

...Locke adverte, o caminho que leva à construção desta sociedade implica um processo gigantesco de educação, e não apenas a educação entendida no sentido da transmissão do conhecimento mas no sentido da formação da cidadania. (Oliveira, p. 181,2000$)$

Daí a instrução se tornar pública como função do Estado e, mais explicitamente, como dever do Estado, a fim de que, após o impulso interventor inicial, o indivíduo pudesse se autogovernar como ente dotado de liberdade e capaz de participar de uma sociedade de pessoas livres.

A importância do ensino primário tornado um direito imprescindível do cidadão e um dever do Estado impôs a gratuidade como modo de torná-lo acessível a todos. Por isso, o direito à educação escolar primária inscreve-se dentro de uma perspectiva mais ampla dos direitos civis dos cidadãos.

Tais direitos vão sendo concebidos, lentamente, como uma herança dos tesouros da civilização humana e, portanto, não é cabível que alguém não possa herdá- 
los. Ao oferecer a educação escolar primária gratuita, o próprio Estado liberal assegura uma condição universal para o próprio usufruto dos direitos civis.

Em todo o caso, a ligação entre o direito à educação escolar e a democracia terá a legislação como um de seus suportes e invocará o Estado como provedor desse bem, seja para garantir a igualdade de oportunidades, seja para, uma vez mantido esse objetivo, intervir no domínio das desigualdades, que nascem do conflito da distribuição capitalista da riqueza, e progressivamente reduzir as desigualdades. A intervenção tornar-se-á mais concreta quando da associação entre gratuidade e obrigatoriedade, já que a obrigatoriedade é um modo de sobrepor uma função social relevante e imprescindível de uma democracia a um direito civil. Essa intervenção, posteriormente, se fará no âmbito da liberdade de presença da iniciativa privada na educação escolar, de modo a autorizar seu funcionamento e pô-la sub lege.

Essa ligação entre a educação e a escolaridade como forma de mobilidade social e de garantia de direitos tem um histórico que é variável de país para país, considerados os determinantes socioculturais de cada um.

Uma análise magistral que invoca a trajetória dos direitos, seja para classificálos, seja para mostrar sua progressiva evolução, é aquela oferecida por um célebre texto de Thomas Marshall (1967). Ele se debruça sobre a experiência da Inglaterra e a partir daí diferencia os direitos e os classifica por períodos. Desse modo, os direitos civis se estabeleceriam no século XVIII, os políticos, no século XIX, e os sociais, no século $X X$. Nessa trajetória o autor fará referências à educação e à instrução escolar.

Para o autor, a história do direito à educação escolar é semelhante à luta por uma legislação protetora dos trabalhadores da indústria nascente, pois, em ambos os casos, foi no século XIX que se lançaram as bases para os direitos sociais como integrantes da cidadania. Segundo Marshall, "a educação é um pré-requisito necessário da liberdade civil” e, como tal, um pré-requisito do exercício de outros direitos. $\bigcirc$ Estado, neste caso, ao interferir no contrato social, não estava conflitando com os direitos civis. Afinal, esses devem ser utilizados por pessoas inteligentes e de bom senso e, para tanto, segundo o autor, o ler e o escrever são indispensáveis.

A educação das crianças está diretamente relacionada com a cidadania, e, quando o Estado garante que todas as crianças serão educadas, este tem em mente, sem sombra de dúvida, as exigências e a natureza da cidadania. Está tentando estimular o desenvolvimento de cidadãos em formação. $O$ direito à educação é um direito social de cidadania genuíno porque o objetivo da educação durante a infância é moldar 
o adulto em perspectiva. Basicamente, deveria ser considerado não como o direito da criança freqüentar a escola, mas como o direito do cidadão adulto ter sido educado. (p. 73)

Em outro momento de sua análise, ele reforça a tese iluminista que, a instrução, deve ser objeto da coerção estatal, já que o ignorante perde as condições reais de apreciar e escolher livremente as coisas. Afinal, a marca do homem burguês é a autonomia com relação a poderes estranhos, e cuja concepção teórica básica se expressa em normas legais, que instituem a igualdade entre os indivíduos e nas suas relações com as coisas.

O final do século XIX demonstra que, na experiência européia, a educação primária era gratuita e obrigatória. A obrigatoriedade não só não era uma exceção ao laissez-faire, como era justificada no sentido de a sociedade produzir pessoas com mentes maduras, minimamente "iluminadas", capazes de constituir eleitorado esclarecido e trabalhadores qualificados. Thomas Marshall (1967), comentando e citando o pensamento do economista liberal neoclássico Alfred Marshall, diz:

.... Estado teria de fazer algum uso de sua força de coerção, caso seus ideais devessem ser realizados. Deve obrigar as crianças a freqüentarem a escola porque o ignorante não pode apreciar e, portanto, escolher livremente as boas coisas que diferenciam a vida de cavalheiros daquela das classes operárias. [... . Ele reconheceu somente um direito incontestável, o direito de as crianças serem educadas, e neste único caso ele aprovou o uso de poderes coercivos pelo Estado...(p. 60, 63)

A ativação desta "luz" que cada um traz consigo e que amplia a capacidade de escolha não poderia ser nem objeto de uma ação assistemática e nem produto de um acaso bem-sucedido.

Como diz Bobbio (1986):

O problema mais difíil para uma teoria racional (ou que pretende ser racional) do Estado é o de conciliar dois bens a que ninguém está disposto a renunciar e que são (como todos os bens últimos) incompatíveis: a obediência e a liberdade. (p. 83)

Mas, se o Estado, como ente racional, deve seguir a razão e seus ditames, cabe a ele assegurar condições para que seus cidadãos ajam segundo o seu próprio arbítrio, para o que são necessárias "as luzes da razão".

Avançando no tempo, mas com uma acuidade teórico-metodológica exemplar, Bobbio (1987) deixa claro um dos sentidos que presidiram a imposição da obrigatoriedade escolar: 
Esta tentativa de escolher as reformas que são ao mesmo tempo liberadoras e igualitárias deriva da constatação de que há reformas liberadoras que não são igualitárias, como seria o caso de qualquer reforma de tipo neoliberal, que oferece ampla margem de manobra aos empresários para se desvencilharem dos vínculos que advêm da existência de sindicatos e comitês de empresa, ao mesmo tempo em que se destina a aumentar a distância entre ricos e pobres; por outro lado, existem reformas igualitárias que não são liberadoras, como toda a reforma que introduz uma obrigação escolar, forçando todas as crianças a ir à escola, colocando a todos, ricos e pobres, no mesmo plano, mas por meio de uma diminuição da liberdade. (p. 23)

Marshall ( 1967$)$, ao apontar a educação primária pública como obrigatória e gratuita, torna a justificá-la:

No período inicial da educação pública na Inglaterra, os direitos eram mínimos e iguais. Mas, como já observamos, ao direito veio corresponder uma obrigação, não apenas porque o cidadão tenha uma obrigação para consigo mesmo, assim como um direito de desenvolver o que se encontra latente dentro de si - um dever que nem a criança nem o pai podem apreciar em toda a sua extensão - mas porque a sociedade reconheceu que ela necessitava de uma população educada. (p. 99)

Esta ruptura com uma concepção individualista de liberdade da sociedade também contém uma base liberal à medida que esta forma de sociedade tem afirmado a relação política não mais como algo ex parte principis, mas como ex parte civium,

...característica da formação do Estado moderno, ocorrida na relação entre Estado e cidadãos: passou-se da prioridade dos deveres dos súditos à prioridade dos direitos do cidadão, emergindo um modo diferente de encarar a relação política, não mais predominantemente do ângulo do soberano, e sim daquele do cidadão, em correspondência com a afirmação da teoria individualista da sociedade em contraposição à concepção organicista tradicional. (Bobbio, 1992, p. 3)

Para participar livremente das tomadas de decisões era preciso ser cidadão e este não se constitui sem o desenvolvimento de sua marca registrada: a razão. A propriedade de si expressa-se na efetivação da razão. Seria, pois, preciso desenvolvêla e estimulá-la, no mínimo combatendo a ignorância.

Desse modo, até com a justificativa de impulsionar o indivíduo na busca da educação, muitos países farão da educação primária uma condição para o exercício dos direitos políticos, em especial o do voto. Por seu lado, muitos movimentos 
operários assumirão a bandeira da educação escolar como forma de obter ganhos sociais mediante a representação parlamentar, cuja base operária estaria presente com o voto dos trabalhadores. Tal perspectiva é desenvolvida por Przeworski ( 1989 ).

Assim, voltando-se à análise de Marshall, ele analisa a educação escolar primária como um serviço extra e de tipo único para o indivíduo. Para ele "o desenvolvimento da educação primária pública durante o século XIX constituiu o primeiro passo decisivo em prol do restabelecimento dos direitos sociais da cidadania no século XX" (p. 74).

Desse modo, mesmo o Estado Liberal do século XIX aceita intervenção do Estado em matéria de educação. A educação primária é vista como uma atividade pertencente ao interesse geral e, portanto, como Adam Smith (1983) já havia dito "o Estado pode facilitar, encorajar e até mesmo impor a quase toda a população a necessidade de aprender os pontos mais essenciais da educação", mesmo que seja em doses homeopáticas. Karl Marx, no capítulo XII, do livro I, de O Capital, referese a Adam Smith, que recomendava a instrução primária "a fim de evitar a degeneração completa da massa do povo, originada pela divisão do trabalho”. Neste sentido, o próprio Adam Smith colocava-se contra as propostas do francês G. Garnier, para quem a instrução primária contraria as leis da divisão do trabalho. Também Stuart Mill havia apontado que

....a educação, portanto, é uma dessas coisas que é admissível, em princípio, ao governo ter de proporcionar ao povo. Trata-se de um caso ao qual não se aplicam necessária e universalmente as razões do princípio da não-interferência [...] É pois um exercício legítimo dos poderes do governo impor aos pais a obrigação legal de dar instrução elementar aos filhos. (1983, p. 404)

Assim, tanto a Inglaterra, como a França, a Alemanha e outros países europeus, no século XIX, fizeram reformas educativas nas quais se cruzam as idéias do pensamento liberal com a ação intervencionista do Estado e com o controle inicial do trabalho infantil. Acreditava-se que a instrução primária seria uma vacina contra o despotismo já vivido por muitos países tanto quanto uma forma de questionar a dominância do trabalho manual, entre os adultos, e a presença de crianças no regime fabril.

$\mathrm{Na}$ verdade, para as classes dirigentes européias, colocar o Estado como provedor de determinados bens próprios da cidadania, como a educação primária e a assistência social, representava a necessidade da passagem progressiva da autoproteção contra calamidades e incertezas para a solução coletiva de problemas 
sociais. Para contar com as classes populares no sentido da solução de muitos problemas, não era mais possível nem deixar de satisfazer algumas de suas exigências e nem ser um privilégio, o que, a rigor, era direito de todos e não só de uma minoria.

Muito instigantes também são as reflexões de Bobbio (1992) que, de certa maneira, retomam a análise histórica dos direitos na busca de uma perspectiva histórica de longo alcance.

Certamente, cada país, dentro de sua situação histórica, conhecerá peculiaridades próprias que não o reduzem ao caminho de um outro. Mas, de todo modo, a divisão periódica proposta por Marshall e as reflexões de Bobbio (1992) sobre a era dos Direitos, sua gênese, evolução e perspectivas, são muito úteis para classificar, no campo dos direitos, e diferenciá-los entre si. No caso, é importante destacar que ambos se referem à educação escolar como um direito imprescindível para a cidadania e para o exercício profissional.

$O$ direito à educação, como direito declarado em lei, é recente e remonta ao final do século XIX e início do século XX. Mas seria pouco realista considerá-lo independente do jogo das forças sociais em conflito.

Tanto a ampliação dos direitos civis e políticos como a inserção de direitos sociais não são apenas uma estratégia das classes dirigentes que aí teriam descoberto, na solução coletiva, diversas vantagens que o anterior sistema de autoproteção não continha.

Esses direitos são também um produto dos processos sociais levados adiante pelos segmentos da classe trabalhadora, que viram nele um meio de participação na vida econômica, social e política. Algumas tendências afirmam a educação como um momento de reforma social em cujo horizonte estaria a sociedade socialista. Para outras tendências, a educação, própria da classe operária e conduzida por ela, indicava uma contestação da sociedade capitalista e antecipação da nova sociedade.

A história da classe trabalhadora, contada por vários historiadores como E.P. Thompson ou Eric Hobsbawn, aponta que a educação se apresentava como uma bandeira de luta de vários partidos, movimentos radicais populares e de vários programas políticos de governo. Thompson ( 1987), por exemplo, relatando um movimento societário em prol dos direitos do homem, escreve que na defesa destes se inclúam "um direito à parcela do produto... proporcional aos lucros do patrão e o direito à educação, pela qual o filho do trabalhador poderia ascender ao nível mais elevado da sociedade" (p. 176).

Esta também é a direção de muitos trabalhos de Adam Przeworski ( 1989 ). $\bigcirc$ autor trata das lutas dos vários partidos europeus de esquerda que, nos diferentes 
países deste continente, se empenharam na busca de vitórias eleitorais acenando bandeiras de reformas. Muitas tendências dos diferentes partidos socialistas que se formaram ao longo do século XIX e início do século XX, desejosos de transformações sociais radicais pelo caminho de maiorias eleitorais, não só lutaram pela escola primária gratuita e obrigatória como também pela sua extensão a níveis mais elevados. Este foi o caso da França em torno da gratuidade do ensino médio e sua obrigatoriedade progressiva. No caso específico da França, a defesa da escola laica era um outro modo de dizer da importância e da responsabilidade do Estado no assunto. Todo um capítulo dedicado à questão da alfabetização no século XIX, na Inglaterra, e sua imperiosa necessidade por parte dos trabalhadores será levado adiante por E.P. Thompson, (1987a, p. 303 ss).

Assim, seja por razões políticas, seja por razões ligadas ao indivíduo, a educação era vista como um canal de acesso aos bens sociais e à luta política e, como tal, um caminho também de emancipação do indivíduo diante da ignorância. Dado este leque de campos atingidos pela educação, ela foi considerada, segundo o ponto de vista dos diferentes grupos sociais - ora como síntese dos três direitos assinalados os civis, os políticos e os sociais ora como fazendo parte de cada qual dos três.

A magnitude da educação é assim reconhecida por envolver todas as dimensões do ser humano: o singulus, o civis, e o socius. $O$ singulus, por pertencer ao indivíduo como tal, o civis, por envolver a participação nos destinos de sua comunidade, e o socius, por significar a igualdade básica entre todos os homens. Essa conjunção dos três direitos na educação escolar será uma das características do século $X X$.

Em muitos casos, como nas constituições da Alemanha (Constituição de Weimar), da então União Soviética e da Espanha republicana, esse direito do cidadão é também declarado, reconhecido como dever dos poderes públicos e inscrito em lei. A garantia do Estado visava diminuir o risco de que as desigualdades já existentes viessem a se transformar em novas modalidades de privilégios. Do mesmo modo como se invocou o poder do Estado para regular as relações de trabalho, este poder se fez presente na educação escolar sobretudo pela imposição da obrigatoriedade e conseqüente gratuidade.

Muitos países, como a França, reconheceram a educação como serviço público e a inseriram dentro do princípio da laicidade. As lutas pela laicidade e por governos civis dependentes do contrato social deram oportunidade para que a escola pública para todos se constituísse verdadeiro apoio da construção da nacionalidade e do acesso ao sistema eleitoral. 
Hoje, em boa parte dos países europeus e mesmo latino-americanos, a discussão do direito à educação escolar já se coloca do ponto de vista do que Bobbio ( 1992) chama de especificação. Na verdade, trata-se do direito à diferença, em que se mesclam as questões de gênero com as de etnia e credo, entre outras. A presença de imigrantes provindos em boa parte das ex-colônias da Europa repõe não só o tema da tolerância como o da submissão dos cidadãos ao conjunto das leis nacionais.

A dialética entre o direito à igualdade e o direito à diferença na educação escolar como dever do Estado e direito do cidadão não é uma relação simples. De um lado, é preciso fazer a defesa da igualdade como princípio de cidadania, da modernidade e do republicanismo. A igualdade é o princípio tanto da não-discriminação quanto ela é o foco pelo qual homens lutaram para eliminar os privilégios de sangue, de etnia, de religião ou de crença. Ela ainda é o norte pelo qual as pessoas lutam para ir reduzindo as desigualdades e eliminando as diferenças discriminatórias. Mas isto não é fácil, já que a heterogeneidade é visível, é sensível e imediatamente perceptível, o que não ocorre com a igualdade. Logo, a relação entre a diferença e a heterogeneidade é mais direta e imediata do que a que se estabelece entre a igualdade e a diferença.

O pensamento "único" ou empírico não aprecia a abstração, preferindo o manifesto, o visível, o palpável. O empírico é necessário e mesmo "porta" de entrada para uma realidade ontológica mais ampla. Esta realidade é o gênero humano, da qual procede o reconhecimento da igualdade básica de todos os seres humanos, fundamento da dignidade de toda e qualquer pessoa humana. É do reconhecimento da igualdade essencial de todas as pessoas do gênero humano que se nutriram todas as teses da cidadania e da democracia. Sem esse reconhecimento e respeito por ele, estão abertas portas e janelas para a entrada de todas as formas de racismo e correlatos de que o século $X X$ deu trágicas provas.

A defesa das diferenças, hoje tornada atual, não subsiste se levada adiante em prejuízo ou sob a negação da igualdade. Estamos assim diante do homem como pessoa humana em quem o princípio de igualdade se aplica sem discriminações ou distinções, mas estamos também ante o homem concreto cuja situação deve ser considerada no momento da aplicação da norma universal.

Por isso, os Estados democráticos de direito zelam em assinalar as discriminações que devem ser sempre proibidas: origem, raça, sexo, religião, cor, crença. Ao mesmo tempo, seria absurdo pensar um igualitarismo, uma igualdade absoluta, de modo a impor uniformemente as leis sobre todos os sujeitos e em todas as 
situações. Um tratamento diferenciado só se justifica perante uma situação objetiva e racional e cuja aplicação considere o contexto mais amplo. A diferença de tratamento deve estar relacionada com o objeto e com a finalidade da lei e ser suficientemente clara e lógica para a justificar.

A França ilustra bem este ponto com o caso dos foulards (véus) usados por jovens muçulmanas, cujos pais têm proibido a freqüência das filhas em aulas de educação física'.

Contudo, o pensamento e a política que caminham no sentido de uma sociedade mais justa não pode abrir mão do princípio da igualdade, a cuja "visibilidade" só se tem acesso por uma reflexão teórica. A não-aceitação da igualdade básica entre todos os seres humanos e o direito a um acesso qualificado aos bens sociais e políticos conduzem a uma consagração "caolha" ou muito perigosa do direito à diferença. Porque sem esta base concreta e abstrata, ao mesmo tempo, do reconhecimento da igualdade, qualquer diferença apontada como substantiva pode se erigir em princípio hierárquico superior dos que não comungam da mesma diferença. Em nossos dias, a negação de categorias universais, porque tidas como aistóricas ou totalitárias, tem dado lugar a uma absolutização do princípio do pequeno, da subjetividade, do privado e da diferença. E isso torna mais problemático o caminho de uma sociedade menos desigual e mais justa.

Ora, essa realidade demonstra que o caminho europeu, no sentido das conquistas de direitos consagrados em lei, nem sempre foi o mesmo dos países que conheceram a dura realidade da colonização. E, mesmo no meio dos países colonizados, ainda resta avaliar o impacto sociocultural da colonização quando acompanhada de escravatura. A conquista do direito à educação, nestes países, além de mais lenta, conviveu e convive ainda com imensas desigualdades sociais. Neles, à desigualdade se soma a herança de preconceitos e de discriminações étnicas e de

I. Como se sabe, após a puberdade, as jovens muçulmanas devem respeitar um certo número de hábitos de conduta relativos ao recato e à exposição do corpo. $\bigcirc$ véu (foulard) que lhes cobre o rosto (ou todo ele, em determinadas tendências do islamismo) é um deles. A França, ciosa de seu republicanismo e laicidade, não aceita no espaço escolar o que lá se denomina de sinais ostentatórios de pertença a agremiações religiosas, políticas ou associativas em geral. A rejeição ao foulard é defendida em nome da igualdade de gênero e/ou da obediência às leis do país. As aulas de educação física exacerbam o problema, já que as jovens se recusam a usar os trajes esportivos exigidos para determinadas práticas. Até meados da década de 90 , este debate permeou a educação francesa e gerou artigos, livros, posições oficiais e práticas diferenciadas por parte dos colegiados das escolas. De modo geral, o problema envolveu a tensão igualdade/diferença e novos olhares sobre a laicidade. 
gênero incompatíveis com os direitos civis. Em muitos destes países, a formalização de conquistas sociais em lei e em direito não chega a se efetivar por causa desses constrangimentos herdados do passado e ainda presentes nas sociedades.

Ao contrário de muitos países europeus, os países colonizados não contaram, desde logo, com processos de industrialização e de constituição de uma forte classe operária. Assim sendo, para as classes dirigentes, a educação não se impôs como uma necessidade socialmente significativa para todos. Não houve um processo social em que um outro ator social forte e organizado abrisse, desde logo, um conflito que cobrasse responsabilidades sociais. Ao ocuparem os aparelhos de Estado, as classes dirigentes se preocuparam muito mais com seus interesses exclusivos do que com um projeto nacional que englobasse dimensões mais amplas da cidadania para todos.

A escravidão, o caráter agrário-exportador desses países e uma visão preconceituosa com relação ao "outro" determinaram uma estratificação social de caráter hierárquico. Nela, o outro não era visto como igual mas como "inferior". Logicamente as elites atrasadas desses países, tendo-se na conta de "superiores", determinaram o pouco peso atribuído à educação escolar pública para todos. Na perspectiva dessas classes dirigentes, era suficiente para as classes populares serem destinatárias da cultura oral. Bastava-Ihes um tipo de catequese em que o "outro" deveria ser aculturado na linha da obediência e da lealdade servil.

Os países latino-americanos, por exemplo, sofreram a colonização ibérica e por ela conheceram o impacto da Contra-Reforma em face da sua população nativa ou escravizada. Para as elites, tais povos eram "selvagens", "incivilizados" e "incultos". Como tais, deveriam ou se conformar docilmente às ordens "superiores" ou se converter aos padrões ocidentais como seres "dependentes".

A leitura e interpretação de livros em geral ou dos livros sagrados eram reservadas aos bacharéis e aos teólogos, autorizados pela Igreja católica. Daí porque a transmissão oral ganha relevância sobre a transmissão baseada no acesso à leitura e à escrita a todos. Tal tradição se opõe à experiência européia dos países que conheceram a Reforma. Neles, a tese luterana da sola fide et sola scriptura implicou não só o desenvolvimento da imprensa como também o incentivo a que todos os fiéis, mediante a instrução, pudessem ler os livros sacros e meditar sobre a palavra de Deus. Por isso, nestes países colonizados será longa e árdua a luta pelo direito à educação em geral e pela educação primária em especial. Não serão fáceis a inscrição e a declaração deste direito nas leis destes países.

Afinal, a emersão da escrita redefine o valor da palavra falada e a subordina 
nas relações contratuais, especialmente aquelas vigentes em torno do trabalho. A colonização e a escravatura, pondo-se fora de relações contratuais em que ao menos juridicamente se reconhece a igualdade entre todos, só apareciam após os processos de abolição e de independência. Mesmo assim, muitos destes países continuarão fortemente agrários e, nesse caso, as classes dominantes terão pouco interesse em difundir a educação escolar e, com ela, a escrita e a leitura.

A própria experiência dos Estados Unidos da América revela que, só na metade do século XIX, a campanha pela educação pública e gratuita para todos, iniciada em Boston por Horace Mann, dará seus frutos.

Preocupadas mais com o seu enriquecimento econômico e preservação de seus privilégios, as elites dos países latino-americanos desconsiderarão a importância efetiva da educação, apesar de muitas falas ao contrário. $\bigcirc$ que não quer dizer que não houvesse iniciativas progressistas a este respeito. A Argentina, ainda que às custas de grande redução de sua população nativa, investiu bastante no direito à educação primária aberta para todos. $\bigcirc$ mesmo pode se dizer da experiência uruguaia. Já no Brasil, por exemplo, a educação primária, durante mais de meio século após sua independência em I 822, será proibida aos negros escravos, ao índios, e as mulheres enfrentarão muitos obstáculos por causa de uma visão tradicionalmente discriminatória quanto ao gênero.

Mesmo com declaraçães e inscrição em lei, o direito à educação ainda não se efetivou na maior parte dos países que sofreram a colonização. As conseqüências da colonização e escravatura, associadas às múltiplas formas de não-acesso à propriedade da terra, a ausência de um sistema contratual de mercado e uma fraca intervenção do Estado no sistema de estratificação social produzirão sociedades cheias de contrastes, gritantes diferenças, próprias da desigualdade social. A persistência desta situação de base continua a produzir pessoas ou que estão "fora do contrato" ou que não estão tendo oportunidade de ter acesso a postos de trabalho e bens sociais mínimos.

Isto explica o enorme número de pessoas que sequer possui educação primária, sendo ainda grande o número de pessoas que possui poucos anos de escolaridade. A pirâmide educacional acompanha muito de perto a pirâmide da distribuição da renda e da riqueza.

Para os tempos contemporâneos, em que vai se constituindo a chamada "sociedade do conhecimento", a distância entre pobres e ricos aumenta também por causa do acesso aos conhecimentos disponíveis e às novas formas de linguagem que necessitam de uma socialização própria. Essa distância também tem aumenta- 
do a distância entre países ricos e países pobres, no momento em que o conhecimento tem-se constituído em mais-valia intelectual e base para o desenvolvimento auto-sustentado dos países.

Isto não quer dizer que se deve diminuir a importância da declaração de direitos. Declarar um direito é muito significativo. Equivale a colocá-lo dentro de uma hierarquia que o reconhece solenemente como um ponto prioritário das políticas sociais. Mais significativo ainda se torna esse direito quando ele é declarado e garantido como tal pelo poder interventor do Estado, no sentido de assegurá-lo e implementá-lo.

A declaração e a garantia de um direito tornam-se imprescindíveis no caso de países, como o Brasil, com forte tradição elitista e que tradicionalmente reservam apenas às camadas privilegiadas o acesso a este bem social. Por isso, declarar e assegurar é mais do que uma proclamação solene. Declarar é retirar do esquecimento e proclamar aos que não sabem, ou esqueceram, que eles continuam a ser portadores de um direito importante. Disso resulta a necessária cobrança deste direito quando ele não é respeitado.

O Brasil, por exemplo, reconhece o ensino fundamental como um direito desde 1934 e o reconhece como direito público subjetivo desde 1988. Em 1967, o ensino fundamental (primário) passa de quatro para oito anos obrigatórios. Ele é obrigatório, gratuito e quem não tiver tido acesso a esta etapa da escolaridade pode recorrer à justiça e exigir sua vaga.

Neste sentido, o direito público subjetivo está amparado tanto pelo princípio que ele o é, assim por seu caráter de base e por sua orientação finalística, quanto por uma sanção explícita quando de sua negação para o indivíduo-cidadão. Para esses oito anos obrigatórios não há discriminação de idade. Qualquer jovem, adulto ou idoso tem este direito e pode exigi-lo a qualquer momento perante as autoridades competentes.

...quando nascem os chamados direitos públicos subjetivos, que caracterizam o Estado de Direito. É com o nascimento do Estado de Direito que ocorre a passagem final do ponto de vista do príncipe para o ponto de vista dos cidadãos. No Estado despótico, os indivíduos singulares só têm deveres e não direitos. No Estado absoluto, os indivíduos possuem, em relação ao soberano, direitos privados. No Estado de Direito, o indivíduo tem, em face do Estado, não só direitos privados, mas também direitos públicos. O Estado de Direito é o Estado dos cidadãos. (Bobbio, 1992, p.61) 
Consagrado por este reconhecimento, o direito público subjetivo implica ao Estado seu dever de atender a todos os maiores de sete anos no cumprimento dos anos da escolaridade obrigatória².

Este jogo entre direito e dever implica aos interessados, quando na falta deste atendimento, o acionar de instrumentos jurídicos e processuais capazes de fazer respeitar um direito claramente protegido. Nesse sentido, a Constituição aciona a própria sociedade civil como espaço consciente de poder e de controle democrático do próprio Estado, a fim de que nenhum cidadão fique sem o benefício da educação escolar.

O direito à educação parte do reconhecimento de que o saber sistemático é mais do que uma importante herança cultural. Como parte da herança cultural, o cidadão torna-se capaz de se apossar de padrões cognitivos e formativos pelos quais tem maiores possibilidades de participar dos destinos de sua sociedade e colaborar na sua transformação. Ter o domínio de conhecimentos sistemáticos é também um patamar sine qua non a fim de poder alargar o campo e o horizonte desses e de novos conhecimentos.

O acesso à educação é também um meio de abertura que dá ao indivíduo uma chave de autoconstrução e de se reconhecer como capaz de opções. $\bigcirc$ direito à educação, nesta medida, é uma oportunidade de crescimento cidadão, um caminho de opções diferenciadas e uma chave de crescente estima de si.

Esta estima de si conjuga-se com a descrição feita por Bobbio (1992) em relação ao desenvolvimento dos direitos. Segundo ele, a gênese histórica de um direito começa como uma exigência social que vai se afirmando até se converter em direito positivo. Esta conversão ainda não significa a universalização do mesmo. O momento da universalização indica que aquela exigência, já posta como direito, se torna generalizada para todos os cidadãos ou amplia os níveis de atendimento. Finalmente há a especificação de direitos. No primeiro caso, temos, por exemplo, o direito à escola primária para os homens livres. Outras categorias passam a exigir este direito e, após muito esforço e luta, pode acontecer tanto a ampliação da escola primária para todas as pessoas de qualquer gênero, idade ou condição social quanto a exigência da inclusão de um nível superior da educação escolar para todos. É o caso da luta pela universalização da escola média.

2. No Brasil, a Constituição Federal implica o Ministério Público à defesa "da ordem jurídica, do regime democrático e dos interesses sociais e individuais indisponíveis (art. 127), promovendo as medidas necessárias a sua garantia" (art. 129). 
Quando organismos internacionais passam a fazer destes direitos um motivo de declarações e de convenções é porque se revela uma tendência de internacionalização, como é o caso do Pacto Internacional sobre Direitos Econômicos, Sociais e Culturais da Assembléia Geral da Onu, de 16.12.66, e a Convenção relativa à luta contra a discriminação no campo do ensino, da Unesco, de 1960.

A especificação acontece quando são reconhecidos novos direitos, como o de as crianças menores de 6 anos terem uma escola adequada à sua idade, ou quando se reconhece, ainda hoje, o direito de as mulheres, os jovens e adultos entrarem nas escolas. Aqui também é o caso dos portadores de necessidades especiais que, por alguma razão, se vêem prejudicados na sua locomoção ou audição ou qualquer outro problema, e passam a exigir um modelo próprio educacional, que atenda às suas peculiaridades.

Ora, donde advém tamanha importância e necessidade reconhecidas à educação?

O direito à educação decorre de dimensões estruturais coexistentes na própria consistência do ser humano.

A racionalidade, expressão da ação consciente do homem sobre as coisas, implica também o desenvolvimento da capacidade cognoscitiva do ser humano como meio de penetração no mundo objetivo das coisas. A racionalidade é também condição do reconhecimento de si, que só se completa pelo concomitante reconhecimento igualitário da alteridade. Só com o desenvolvimento destas capacidades é que a ação do homem com o outro e sobre as coisas torna-se humana e criativa. $\bigcirc$ pleno desenvolvimento da pessoa não poderia se realizar sem o desenvolvimento efetivo da capacidade cognitiva, uma marca registrada do homem. Assim sendo, essa marca se torna universal. Ela é a condensação de uma qualidade humana que não se cristaliza, já que implica a produção de novos espaços de conhecimento, de acordo com momentos históricos específicos.

E como os atores sociais sabem da importância que o saber tem na sociedade em que vivem, o direito à educação passa a ser politicamente exigido como uma arma não violenta de reivindicação e de participação política.

Desse modo, a educação como direito e sua efetivação em práticas sociais se convertem em instrumento de redução das desigualdades e das discriminações e possibilitam uma aproximação pacífica entre os povos de todo o mundo.

A disseminação e a universalização da educação escolar de qualidade como um direito da cidadania são o pressuposto civil de uma cidadania universal e parte daquilo que um dia Kant considerou como uma das condições "da paz perpétua": o 
caráter verdadeiramente republicano dos Estados que garantem este direito de liberdade e de igualdade para todos, entre outros.

Ao mesmo tempo a relação que se estabelece entre professor e aluno é de tal natureza que os conteúdos e os valores, ao serem apropriados, não se privatizam. Quanto mais processos se dão, mais se multiplicam, mais se expandem e se socializam. A educação, com isto, sinaliza a possibilidade de uma sociedade mais igual e humana.

\section{REFERÊNCIAS BIBLIOGRÁFICAS}

BOBBIO, N. A Era dos direitos. Rio de Janeiro: Campus, 1992.

. Reformismo, socialismo e igualdade. Novos Estudos, n. 19, p. 23, dez. 1987.

BOBBIO, N.; BOVERO, M. Sociedade e Estado na filosofia política moderna. São Paulo: Brasiliense, 1986.

CARVALHO, J. M. El Desenvolvimiento de la ciudadania en Brasil. Mexico: Fondo de Cultura Económica, 1995.

FÁVERO, O. (org). A Educação nas constituintes brasileiras. 2. ed. Campinas: Autores Associados, 2001 .

MARSHALL, T. Cidadania, classe social e status. Rio de Janeiro: Zahar, 1967.

MARX, K. O Capital: crítica da economia política, São Paulo: Abril Cultural, 1983, v. I, t. I.

MELLO, C. A. B. Conteúdo jurídico do princípio da igualdade. 3. ed. São Paulo: Malheiros, 2001 .

MILL, I. S. Princípio de economia política: com algumas de suas aplicações à filosofia social, São Paulo: Abril Cultural, 1983, v. II.

OLIVEIRA, I. A. R. Sociabilidade e direito no liberalismo nascente. Revista Lua Nova, n. 50, p. 160, 2000, v. II.

PRZEWORSKI, A. Capitalismo e social-democracia. São Paulo: Cia das Letras, 1989.

SMITH, A. A Riqueza das nações: investigação sobre sua natureza e suas causas. São Paulo: Abril Cultural, 1983, v. II.

THOMPSON, E. P. A Formação da classe operária. Rio de Janeiro: Paz e Terra, 1987. Cap. I, p. 176: As Árvores da liberdade.

. A Formação da classe operária. Rio de Janeiro: Paz e Terra, 1987a. Cap. III, p. 303: A Força dos trabalhadores. 